Korean J. Ecol., 25(1): 41 44, 2002

\title{
Weight Loss and Nutrients Dynamics during the Decomposition of Fine Roots
}

\author{
Pyo, Jae-Hoon, Chang-Hwan Shin, Jeong Namgung, Jeong-Hee Kim \\ and Hyeong-Tae Mun* \\ Department of Biology, Kongju National University, Kongju 314-701, Korea
}

\begin{abstract}
Weight loss, $\mathrm{N}$ and $\mathrm{P}$ dynamics during decomposition of fine roots $(<2 \mathrm{~mm})$ of alder(Alnus japonica), oak (Quercus acutissima) and pitch pine(Pinus rigida) were studied for 33 months in Kongju, Korea. After 33 months, remaining weight of fine roots of alder, oak and pitch pine was $29.2 \%, 47.7 \%$ and $53.4 \%$ of the initial weight, respectively. The decomposition rate constant $(k)$ for alder, oak and pitch pine was $0.448 \mathrm{yr}^{1}, 0.269 \mathrm{yr}^{1}$, $0.228 \mathrm{yr}^{1}$, respectively. Initial concentration of $\mathrm{N}$ and $\mathrm{P}$ in fine roots was $10.32 \mathrm{mg} / \mathrm{g}$ and $0.69 \mathrm{mg} / \mathrm{g}$ for alder, $6.20 \mathrm{mg} / \mathrm{g}$ and $0.37 \mathrm{mg} / \mathrm{g}$ for oak and $7.26 \mathrm{mg} / \mathrm{g}$ and $0.44 \mathrm{mg} / \mathrm{g}$ for pitch pine, respectively. Initial concentration of $\mathrm{N}$ and $\mathrm{P}$ in alder were higher than those in oak and pitch pine. After 33 months, remaining $\mathrm{N}$ and $\mathrm{P}$ in fine roots was $39.5 \%$ and $31.8 \%$ for alder, $59.4 \%$ and $57.8 \%$ for oak, $63.0 \%$ and $83.4 \%$ for pitch pine, respectively. Decomposition rate and the rate of $\mathrm{N}$ released from decomposing fine roots was positively correlated with the initial $\mathrm{N}$ concentration of the fine roots.
\end{abstract}

Key words: Alnus japonica, Decomposition rate, Fine roots, Nutrients dynamics, Pinus rigida, Quercus acutissima

\section{INTRODUCTION}

Fine roots are important structural and functional components of forest ecosystems (Persson 1980, Chen et al. 2002). Much of the carbon assimilated by plants is allocated to fine roots production, resulting in a large flux of organic matter and nutrients into the soil system (Vogt et al. 1986, Hendrick and Pregitzer 1993, Kurz et al. 1996, Cairns et al. 1997). Carbon and nutrients returned to the soil from fine roots decomposition equals or surpasses that returned through leaf litter in many forests (Hendrick and Pregitzer 1992). Although tree root systems store large amounts of organic matter and nutrients in forest ecosystems, information on the decay rates of fine roots and nutrients dynamics during fine-root decomposition is not much, especially compared with the wealth of data on aboveground litter decomposition (Gosz et al. 1973, Fogel and Cromack 1977, Harmom et al 1990). Thus it needs more fine-roots decomposition studies to understand the nutrient cycling of forest ecosystems.

The major biotic factors which affect root decomposition include nitrogen and lignin content in roots as well as decomposer community present in the soil (Berg 1984, Hobbie 1996, Chen et al. 2001). Among the biotic factors, the initial lignin/ $\mathrm{N}$ ratio in roots seems to be the best predictor of root decomposition (McClaugherty et al. 1984, Aber et al. 1990, Hobbie 1996). A variety of abiotic factors also affect root decomposition. Among the abiotic factors, soil temperature and moisture content of roots are considered as the main factors affecting root decomposition (Vogt et al. 1986, Hobbie 1996, Chen et al. 2000).

This paper presents the 33 months data of fine-root decomposition. The purpose of this study is to investigate the decay rates of fine roots of some tree species and nutrients dynamics during decomposition in a temperate forest.

\section{MATERIALS AND METHODS}

\section{Study area}

This study was conducted in an oak forest which is distributed 100 to $230 \mathrm{~m}$ altitude on east facing slope with $20^{\circ}$ inclination in Kongju, Korea. Oak forest in this study area has preserved well because the general public are not permitted to enter in this area since around 1920. Quercus acutissima is the dominant tree species and some $Q$. variabilis occurred in tree layer. Height of tree layer was about $20 \mathrm{~m}$, and average $\mathrm{DBH}$ was $21.2 \mathrm{~cm}$. In shrub layer, Lindera obtusiloba, Stephanandra incisa, Rhus trichocarpa, Rosa multiflora, Prunus sargentii, Lindera erythrocarpa, Viburnum burejaeticum are occurred.

Monthly precipitation, mean temperature and mean soil temperature during the study period was depicted in Fig. 1 and Fig. 2. Climatic data was obtained from Buyo meteorological station $32 \mathrm{~km}$ distance from the study area. Annual precipitation in 1999 and 2000 was 1,530 and $1,521 \mathrm{~mm}$, respectively. However,

* Author for correspondence; Phone: 82-41-850-8499, Fax: 82-41-850-8479, e-mail: htmun@kongju.ac.kr 
annual precipitation in 2001 was much lower than previous years with the value of $753 \mathrm{~mm}$. Soil temperature was measured at $1 \mathrm{hr}$ intervals with Thermo Recorder (TR-72S) at $5 \mathrm{~cm}$ and $10 \mathrm{~cm}$ soil depth.

\section{Root preparation}

Fine roots of alder, oak and pitch pine were obtained from each stand in Kongju in October 1998. Pitch pine is coniferous and aider and oak are deciduous. We followed lateral roots originating from woody roots of each species, because it was not easy to distinguish fine roots from other species. The fine root system was defined as roots $<2 \mathrm{~mm}$ in diameter and their associated root tips. Collected fine roots were cleaned by rinsing with tap water in laboratory, and dried at $60^{\circ} \mathrm{C}$ to a constant weight.

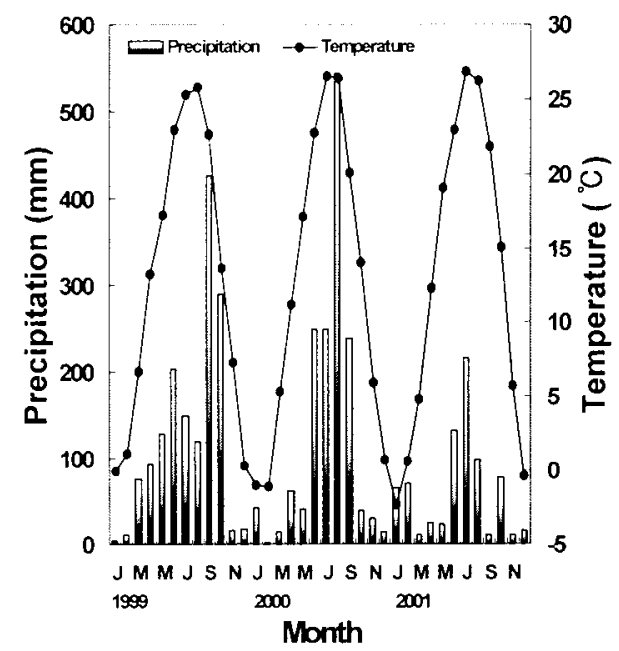

Fig. 1. Monthly precipitation and average temperature at Buyo meteorological station about $32 \mathrm{~km}$ distance from the study site.

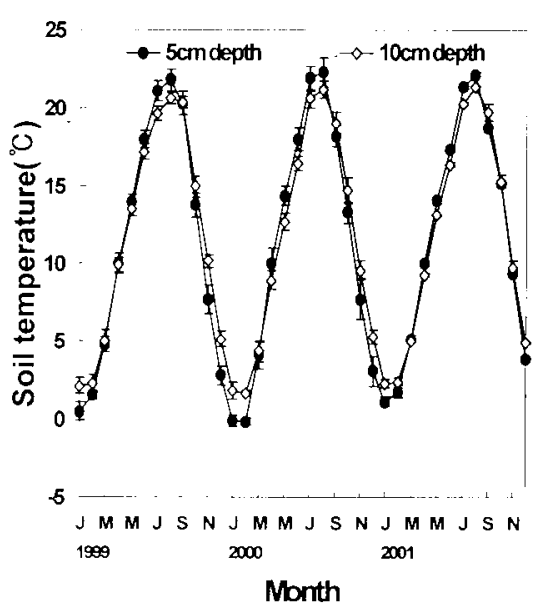

Fig. 2. Mean monthly soil temperature at $5 \mathrm{~cm}$ and $10 \mathrm{~cm}$ soil depth at the study site.

\section{Root litter-bag preparation}

Root litter-bags, $15 \times 15 \mathrm{~cm}$, were made of nylon mesh with 2$\mathrm{mm}^{2}$ holes. We prepared 50 litter-bags in each species. Each root litter-bag enclosed about $5 \mathrm{~g}$ of root and an alumnum tag which giving the exact weight of the root. The root litter-bag openings were sealed with impulse sealer (monel staples). Root litter-bags were buried at $10-15 \mathrm{~cm}$ depth in the forest floor in December 1998.

\section{Root litter-bag retrieval and treatment}

The first retrieval of root litter-bags was done on January 1999 , 1-month after installation, and then retrieved every 3-months till March 2000, and then 6-months intervals till September 2001. Five root litter-bags of each species was retrieved on each sampling. Adhering material on the outside of the root litter-bags were removed with tap water. Remaining roots in each root litterbag was weighed individually after drying for $72 \mathrm{hr}$ at $60^{\circ} \mathrm{C}$. Dried root samples were ground in mill and passed through $1 \mathrm{~mm}$ screen. Samples were stored in air-tight container to prevent moisture changes prior to analyses for $\mathrm{N}$ and $\mathrm{P}$ content.

Weight loss and changes of nutrients during decomposition were determined by measuring the remaining weight and nutrient concentration of roots in the root litter-bags. Weight loss of the root was expressed as \% of the initial sample weight. The decomposition rate constant $(k)$ is derived from the exponential decay formula,

$$
X_{t}=X_{0} e^{-k t}
$$

where $X_{0}$ is the percentage of initial mass of fine roots. $X_{t}$ is the percentage of initial mass remaining at time $t$, and $t$ in years (Brinson et al. 1981, Chen et al. 2002). Comparisons of mean weight loss among the three species were carried out using Student' $s t$ test with SPSS 8.0 program for Windows.

\section{Chemical analysis}

Total $\mathrm{N}$ and total $\mathrm{P}$ was determined by Autoanalyzer (Lachat: QuickChem 8000) after wet digestion. Remaining nutrients in the root litter-bags at each sampling date was calculated using the concentration of nutrient in the roots and the weight of the remaining roots in the litter-bags. Each remaining nutrients was expressed as a percentage of the amount contained in the initial root litter-bags.

\section{RESULTS AND DISCUSSION}

\section{Weight loss}

Fine roots showed a rapid weight loss during the first 12 months, followed by a slowing of the decomposition rate except for alder (Fig. 3). Weight loss of $A$. japonica was significantly greater than those of $Q$. acutissima and $P$. rigida $(p<0.01)$. After 
33-months, remaining weight of alder, oak and pitch pine was $29.2,47.7$ and $53.4 \%$ of the initial weight, respectively. The decomposition rate constant $(k)$ for alder, oak and pitch pine was $0.448 \mathrm{yr}^{-1}, 0.269 \mathrm{yr}^{-1}, 0.228 \mathrm{yr}^{-1}$, respectively. Chen et al. (2002) reported that the decomposition rate constant for 15 species examined ranged from $0.172 \mathrm{yr}^{-1}$ for Picea engelmanni to 0.386 $\mathrm{yr}^{-1}$ for Fraxinus latifolia. They reported that red alder lost about $55 \%$ of its initial mass during the 2 year decomposition. In our study, however, alder lost about $65 \%$ of its initial mass during the 2 years decomposition. Pitch pine and oak lost about $43 \%$ and $38 \%$ of its initial mass during the 2 years decomposition. During the first 21 months decomposition, fine roots of pitch pine lost more than that of oak. Thereafter, oak lost more rapidly than pitch pine.

\section{$\mathrm{N}$ and $\mathrm{P}$ dynamics}

Initial N concentration of fine roots of alder, oak and pitch pine was $10.32 \mathrm{mg} / \mathrm{g}, 6.20 \mathrm{mg} / \mathrm{g}, 7.26 \mathrm{mg} / \mathrm{g}$, respectively. The nitrogen content of the decomposing fine roots of the three species exhibited a decrease in first month and then showed a increasing trend over time (Fig. 4A). Increasing trend was more obvious in alder than other species. Nitrogen content of oak consistently lower than the other two species during decomposition. After 33

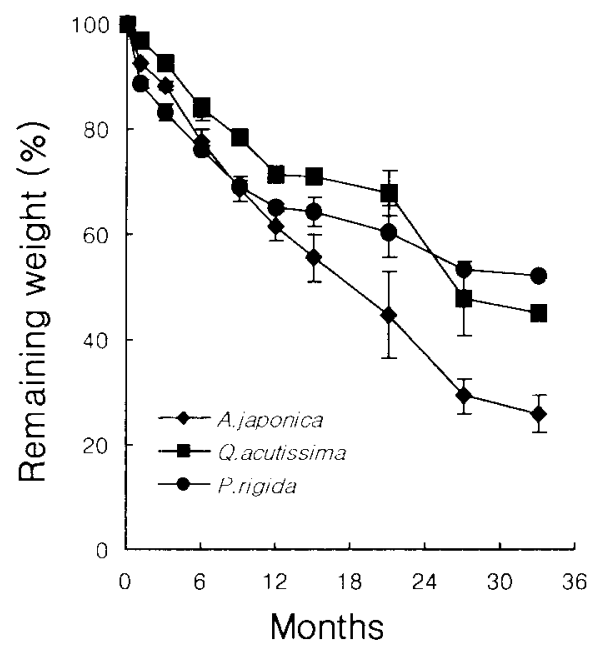

Fig. 3. Mean percent remaining weight in the decomposing fine roots of alder, oak and pitch pine. Bars indicate standard deviation.

months decomposition, nitrogen concentration of alder, oak and pitich pine was $15.7 \mathrm{mg} / \mathrm{g}, 8.2 \mathrm{mg} / \mathrm{g}$ and $8.8 \mathrm{mg} / \mathrm{g}$, respectively.

Nitrogen was released from all three species during the 33 months of decomposition (Fig. 4B). After 1 year of decomposi-
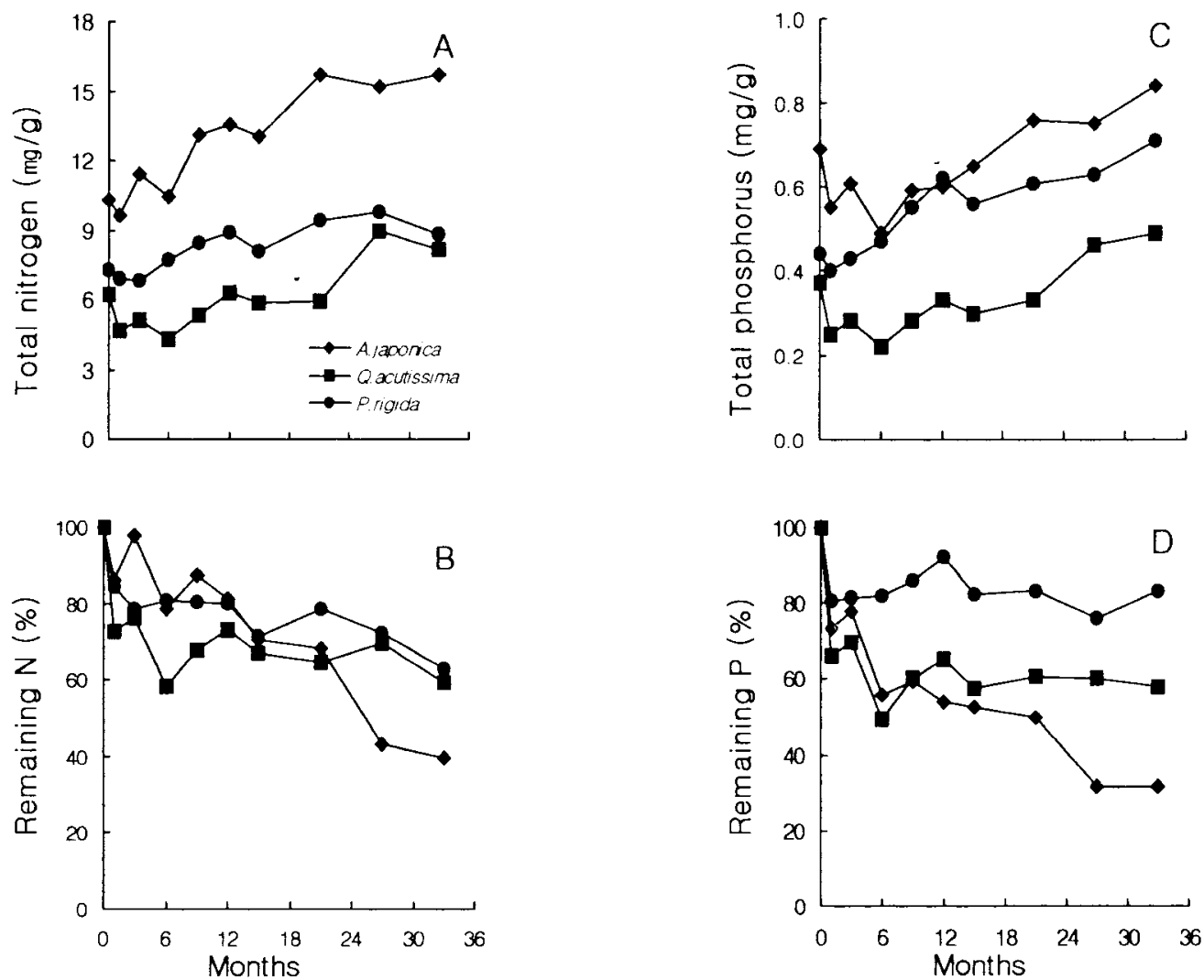

Fig. 4. Changes of $N$ content $(A), \%$ of remaining $N(B), P$ content $(C)$ and $\%$ of remaining $P(D)$ in the decomposing fine roots of alder, oak and pitch pine. 
tion, the decomposing fine roots of alder, oak and pitch pine released $19.9,27.1$ and $20.1 \%$ of initial nitrogen content. After 33 months of decomposition, however, the fine roots of alder released about $60 \%$ of initial nitrogen content (Fig. 4B). During the same period, decomposing fine roots of oak and pitch pine released about $40 \%$ and $37 \%$, respectively, of their initial nitrogen content.

Chen et al. (2002) reported that the initial $\mathrm{N}$ concentration of fine roots accounted for $80 \%$ of the variation in the rate of $\mathrm{N}$ release. They suggested that the mean threshold value of initial $\mathrm{N}$ concentration is $0.4 \%$ of the dry mass. That is, as long as the initial $\mathrm{N}$ concentration of fine roots was higher than $0.4 \%$, roots would release $\mathrm{N}$ during 2 years of decomposition. The initial $\mathrm{N}$ concentration of fine roots in this study, ranging from 0.62 to $1.03 \%$, was much higher than $0.4 \%$

Initial $P$ concentration of fine roots of alder, oak and pitch pine was $0.69 \mathrm{mg} / \mathrm{g}, 0.37 \mathrm{mg} / \mathrm{g}, 0.44 \mathrm{mg} / \mathrm{g}$, respectively. The phosphorus content of the decomposing fine roots of the three species also exhibited a decrease in first 1 month and then showed a increasing trend over time (Fig. 4C). Phosphorus content of oak consistently lower than the other two species during decomposition. After 33 months decomposition, phosphorus concentration of alder, oak and pitch pine was $0.84 \mathrm{mg} / \mathrm{g}, 0.47$ $\mathrm{mg} / \mathrm{g}$ and $0.71 \mathrm{mg} / \mathrm{g}$, respectively.

Phosphorus was also released from three species during the 33 months of decomposition (Fig. 4D). After 1 year of decomposition, the decomposing fine roots of alder, oak and pitch pine released $46.4,35.0$ and $7.7 \%$ of initial phosphorus content. After 33 months of decomposition, however, the fine roots of alder released about $68 \%$ of initial phosphorus content (Fig. 4D). During the same period, decomposing fine roots of oak and pitch pine released about $42 \%$ and $17 \%$, respectively, of their initial phosphorus content.

\section{ACKNOWLEDGEMENTS}

This work was supported by Korea Research Foundation (Grant 2000-041-D00255).

\section{LITERATURE CITED}

Aber, J. D., J. M. Melillo and C. A. McClaugherty. 1990. Prediction long-term patterns of mass loss, nitrogen dynamics and soil organic matter formation from initial litter chemistry in temperate forest ecosystems. Can. J. Bot. 68:22012208.

Berg, B. 1984. Decomposition of root litter and some factors regulating the process: long-term root decomposition in Scots pine forest. Soil Biol. Biochem. 16:609-617.
Brinson, M. M., A. E. Lugo and S. Brown. 1981. Primary productivity, decomposition and consumer activity in fresnwater wetlands. Annu. Rev. Ecol. Syst. 12:123-161.

Cairns, M. A., S. Brown, E. H. Helmer and G. A. Baumgardner 1997. Root biomass allocation in the world's upland forest. Oecclogia 111:1-11.

Chen, H., M. E. Harmon, R. P. Griffiths and B. Hicks. 2000. Effects of temperature and moisture on $C$ respired from decomposing woody roots. For. Ecol. Manage. 138:51-64.

Chen, H., M. E. Harmon and R. P. Griffiths. 2001. Decomposition and nitrogen release from decomposing woody roots in coniferous forests of the Pacific Northwest: a chronosequence approach. Can. J. For. Res. 31:246-260.

Chen, H., M. E. Harmon, J. Sexton and B. Fasth. 2002. Fine-root decomposition and $\mathrm{N}$ dynamics in coniferous forests of the Pacific Northwest, U.S.A. Can. J. For. Res. 32:320-331.

Fogel, R. and K. Cromack, Jr. 1977. Effect of habitat and substrate quality on Douglas-fir litter decomposition in western Oregon. Can. J. Bot. 55:1632-1640.

Gosz, J. R, G. E. Likens and F.H. Bormann. 1973. Nutrient release from decomposing leaf and branch litter in the Hubbard Brook Forest, New Hampshire. Ecol. Monogr. 43:173-191.

Harmon, M. E., G. A. Baker, G. Spycher and S. E. Greene 1990. Leaf litter decomposition in the Picea-Tsuga forests of Olympic National Park, Washington, U.S.A. For. Ecol. Manage. 31:55-66.

Hendrick, R. L. and K. S. Pregitzer. 1992. The demography of fine roots in a northern hardwood forest. Ecology 73:10941104.

Hendrick, R. L. and K. S. Pregitzer. 1993. Patterns of fine root mortality in two sugar maple forests. Nature 361:59-51.

Hendrick, R. L. and K. S. Pregitzer. 1996. Temporal and depthrelated patterns of fine root dynamics in northern hardwood forests. J. Ecology 84:167-176.

Hobbie, S. H. 1996. Temperature and plant species control over litter decomposition in Alaskan Tundra. Ecol. Monogr. 66:503-522.

Kurz, W. A., S. J. Beukema and M. J. Apps. 1996. Estimation of root biomass and dynamics for the $\mathrm{C}$ budget model of the Canadian forest sector. Can. J. For. Res. 26:1973-1979.

McClaugherty, C. A., J. D. Aber and J. M. Melillo. 1984. Decomposition dynamics of fine roots in forested ecosystems. Oikos 42:378-386.

Persson, H. 1980. Spatial distribution of fine-root growth, mortality and decomposition in a young Scots pine stand in Central Sweden. Oikos 34:77-87.

Vogt, K. A., C. C. Grier and D. J. Vogt. 1986. Production, turnover and nutrient dynamics of above- and below-ground detritus of world forests. Adv. Ecol. Res. 15: 303-366.

(Received February 25, 2002, Accepted March 15, 2002) 